\title{
Interactive comment on "A 439-year daily discharge dataset (1861-2299) for the upper Yangtze River, China” by Chao Gao et al.
}

\section{Chao Gao et al.}

gaoqinchao1@163.com

Received and published: 22 December 2019

The comment was uploaded in the form of a supplement:

https://www.earth-syst-sci-data-discuss.net/essd-2019-89/essd-2019-89-AC1-

supplement.pdf

Interactive comment on Earth Syst. Sci. Data Discuss., https://doi.org/10.5194/essd-2019-89, 2019. 